\title{
Generic affiliations of Canthium species placed under Pyrostria group B sensu Bridson (Vanguerieae, Rubiaceae) inferred from morphology and molecular data
}

\author{
Grecebio Jonathan D Alejandro 1,2,3, Carizza Marie M Magdaleno', Joseph Alvin T Pacia', Lyn D Paraguison³,
} Kim Karlo C Quiogue ${ }^{1}$, Annie Eliza D Wong ${ }^{1}$, Krysten Marie R Yayen ${ }^{1}$ and Axel H Arriola ${ }^{3,4^{*}}$

\begin{abstract}
Background: Pyrostria sensu lato (s.l.) is regarded as one of the polyphyletic group within Vanguerieae formerly comprising of Pyrostria sensu stricto (s.s.), Pyrostria group A and Pyrostria group B delineated by the number of locules and geographical occurrence. Recent molecular phylogenetic studies within the genus have narrowed its circumscription that resulted in the merging of Pyrostria group A and Pyrostria s.s. Although some species of Pyrostria group B were already transferred to Pyrostria s.s. and Psydrax based on morphology, other representatives of the group remain unsettled.

Results: Bayesian and parsimony analysis of the combined ITS (nrDNA) and trnL-F (cpDNA) datasets showed a well-supported clade of the whole Vanguerieae containing four Philippine endemic representatives of Pyrostria group B. The placement of Canthium oligophlebium, Canthium obovatifolium and Canthium ramosii within Pyrostria s.s. $(\mathrm{PP}=0.99 ; \mathrm{BS}=85 \%)$ is robustly supported likewise the affiliation of $C$. gynochthodes with Psydrax $(P P=0.94$; BS $=85 \%)$. Morphological features shared by our species with Pyrostria s.s. and Psydrax further supports our molecular data.

Conclusion: Our study supports the earlier hypothesis that Canthium oligophlebium, C. obovatifolium and C. ramosii should be placed under Pyrostria s.s. except for C. gynochthodes that grouped with Psydrax. Four new combinations are proposed in this study. The generic affiliations of other species of Pyrostria group B should be reinvestigated towards a more natural classfication in Vanguerieae.
\end{abstract}

Keywords: Bayesian analysis; ITS; Psydrax; Pyrostria; trnL-F; Vanguerieae

\section{Background}

The tribe Vanguerieae has long been regarded as monophyletic since it is easily delineated from the rest of Rubiaceae by the presence of a unique type of pollen presenter above the style (Verdcourt 1987; Bridson 1992). Recent molecular phylogenetic studies of the tribe (Lantz et al. 2002; Lantz and Bremer 2004, 2005)

\footnotetext{
* Correspondence: arriolaaxel@yahoo.com

${ }^{3}$ The Graduate School, University of Santo Tomas, España, Manila 1015, Philippines

${ }^{4}$ Department of Biological Sciences, College of Arts and Sciences, University of the East, 2219 C.M. Recto Ave, Manila, Philippines

Full list of author information is available at the end of the article
}

support previous classifications of Bridson (1985, 1986, 1992) in reinstating Keetia E. Phillips and Psydrax Gaertn. and raising Canthium subg. Afrocanthium Bridson to a genus level. Meanwhile, Vangueria Juss. was recircumscribed and is distinguished from its close relatives by having inflorescences borne from where leaves have fallen, small bracteoles in secondary branch and large fruit with 2 to 5 locules. The genus Canthium was regarded as highly polyphyletic and redelimited to include species with supraaxillary spines.

Although major evolutionary lineages and new generic limits have been established within Vanguerieae utilizing 
morphology and molecular data, there are still understudied species. When Bridson (1987) reinstated the genus Pyrostria Comm. ex A. Juss., she lumped all Pyrostria species and representatives of Canthium with pair of persistent connate bracts (bracteate species) under Pyrostria s.l. and suggested informal groups (Pyrostria s.s., Pyrostria group A and Pyrostria group B) based on the number of locules and geographical occurrence. Both Pyrostria s.s. (pluri-locular ovary) and Pyrostria group A (bilocular ovary) have unisexual flowers and well represented in Madagascar, the latter extends from Africa to Arabia. Meanwhile, Pyrostria group B shares characters with Pyrostria group A in having unisexual flowers, bilocular ovaries, broad corolla tube, and 4-5 corolla lobes but the former radiates as far as SE Asia. The polyphyly of Pyrostria s.l. was initially addressed by Lantz and Bremer (2004) in recovering a clade composed mainly of dioecious species but failed to discussed further this group due to the poor internal support. Razafimandimbison et al. (2009) established a new generic delimitations using molecular data within the dioecious Vanguerieae by lumping species from Pyrostria group A to Pyrostria s.s. Their study, however, failed to include any species under Pyrostria group B and made an assumption that this group belongs to Pyrostria s.s. due to the presence of paired bracts which is a typical character for this genus. In an earlier study based on morphology, Utteridge and Davis (2009) transferred two SE Asian Canthium species belonging to Pyrostria group B (C. brunnescens Craib and C. cochinchinense Pierre ex Pit. in H.Lecomte) to Pyrostria s.s. Recently, Alejandro et al. (2013) transferred the Philippine endemic C. subsessifolium (Merr.) Merr. to Pyrostria. In contrast, Plectronia amplifolia Elmer informally placed under Pyrostria group B was transferred to Psydrax (Ruhsam et al. 2008).

There are still left unresolved endemic Philippine species placed under Pyrostria group B probably associated with Pyrostria such as C. brunneum (Merr.) Merr., C. ellipticum (Merr.) Merr., C. gynochthodes Baill., C. megacarpum (Merr.) Merr., C. obovatifolium (Merr.) Merr., C. oligophlebium (Merr.) Merr., C. ramosii (Merr.) Merr., and C. subcapitatum (Merr.) Merr. Available herbarium materials of these species are scarce and lack reproductive parts for confirmation. In this study, four species of Canthium informally placed under Pyrostria group B: C. gynochthodes, C. obovatifolium, C. oligophlebium, and C. ramosii were collected and challenged their phylogenetic positions within Vanguerieae utilizing molecular sequence data. Furthermore, type specimens were meticulously examined to confirm our molecular results. The present study is a good contribution in understanding a more robust phylogenetic evolutionary trends and lineages within the tribe.

\section{Methods}

\section{Taxon sampling}

This study is based on the examination of herbarium sheets from various herbaria as well as field observation. Canthium gynochthodes, C. obovatifolium, C. oligophlebium and $C$. ramosii were collected based on their type protologues. Collected samples (herbarium specimens and preserved reproductive structures in $70 \%$ ethanol) were deposited at the USTH for accessioning. Leaf samples were dried in silica-gel for DNA extraction (Chase and Hills 1991).

\section{Molecular methods}

Genomic DNA was extracted from silica gel-dried leaf samples using the DNeasy Plant Minikit (Qiagen, Germany). The entire ITS region (including the $5.8 \mathrm{~S}$ gene) was amplified and sequenced using the primer pair P17F/26-82R and P16F/P25R (Popp and Oxelman 2001). Meanwhile, primer pair c/f were used for both amplification and sequencing of the trnL-F region (Taberlet et al. 1991). DNA amplification was carried out following the work of Alejandro et al. $(2005,2011)$. Amplified DNA was purified using the QIA-quick Purification Kit (Qiagen, Germany). Purified DNA was sent to MACROGEN Inc., Seoul, South Korea for sequencing.

\section{Phylogenetic analysis}

The ITS and $\operatorname{trnL}-F$ sequences were assembled and edited using the Codon Code Aligner version 3.0.1. Novel sequences of the four Philippine Canthium from each of the markers used were incorporated with several related sequences from the work of Lantz and Bremer (2004) taken from the GenBank (Table 1). Ixora coccinea L. and Mussaenda erythrophylla Schumach. \& Thonn., considered as closely related to Vanguerieae were used as the outgroups. Sequences were aligned manually using Se-Al v.1.0al (Rambaut 1996).

Bayesian inference (BI) was used to estimate phylogenetic positions of the Philippine endemic Canthium species. The analysis was carried out using the MrBayes v.3.1.2p software (Huelsenbeck and Ronquist 2001; Ronquist and Huelsenbeck 2003; Altekar et al. 2004). Model selection for the best-performing evolutionary models were determined under three model selection criteria: a) Akaike Information Criterion (AIC) (Akaike 1974), b) AICc (seconder order criterion of AIC, necessary for smaller samples) and c) the Bayesian Information Criterion (BIC) (Schwartz 1978). The selected models were HKY and GTR + G for the ITS and trnL-F, respectively. In analyzing single marker, the best performing model was selected and one million generation was considered with a sample frequency of 1000 and four parallel chains. For combined analyses, model selection as well as the settings is similar with that of the single-marker analysis, however there 
Table 1 Nucleotide sequence database accession numbers of taxa used in this study

\begin{tabular}{|c|c|c|}
\hline \multirow[t]{2}{*}{ Taxon } & \multicolumn{2}{|c|}{ GenBank/EMBL Accession Number } \\
\hline & ITS & trnL-F \\
\hline Afrocanthium burttii (Bullock) Lantz & AJ617749 & AJ620120 \\
\hline Afrocanthium gilfillanii (N.E. Br.) Lantz & AJ617751 & AJ620123 \\
\hline Afrocanthium keniense (Bullock) Lantz & AJ617753 & AJ620126 \\
\hline Afrocanthium lactescens (Hiern) Lantz & AJ617754 & AJ620127 \\
\hline Afrocanthium mundianum (Cham. \& Schltdl.) Lantz & AJ315107 & AJ620128 \\
\hline Afrocanthium parasiebenlistii (Bridson) Lantz & AJ617756 & AJ620130 \\
\hline Afrocanthium pseudoverticillatum (S. Moore) Lantz & AJ617758 & AJ620132 \\
\hline Afrocanthium siebenlistii (K. Krause) Lantz & AJ617759 & AJ620133 \\
\hline Canthium ciliatum (D. Dietr.) Kuntze & AJ617750 & AJ620121 \\
\hline Canthium coromandelicum (Brum. f.) Alston & AJ315081 & AJ620122 \\
\hline Canthium glaucum Hiern ssp. glaucum & AJ617752 & AJ620124 \\
\hline Canthium gynochthodes $^{1}$ & HG937666 & HG937663 \\
\hline Canthium inerme (L.f.) Kuntze & AJ315120 & AJ620125 \\
\hline Canthium mrimaense (Verdc.) Lantz & AJ617775 & AJ620174 \\
\hline Canthium obovatifolium (Merr.) Merr. ${ }^{2}$ & HG937664 & HG937661 \\
\hline Canthium oligocarpum Hiern ssp. Captum (Bullock) Bridson & AJ617755 & AJ620129 \\
\hline Canthium oligophlebium (Merr.) Merr. ${ }^{3}$ & HG937665 & HG937660 \\
\hline Canthium ramosii (Merr.) Merr. ${ }^{4}$ & HG937667 & HG937662 \\
\hline Fadogia ancylantha Schweinf. & AJ315103 & AJ620136 \\
\hline Fadogia arenicola K.Schum. \& K.Krause & AJ874981 & AJ874943 \\
\hline Fadogia tetraquetra K. Schum. \& K. Krause & AJ315099 & AJ620139 \\
\hline Fadogia triphylla Baker & AJ874982 & AJ874944 \\
\hline Keetia gueinzii (Sond.) Bridson & AJ315117 & AJ620143 \\
\hline Keetia lukei Bridson & AJ617761 & AJ620144 \\
\hline Keetia venosa (Oliv.) Bridson & AJ617762 & AJ620145 \\
\hline Keetia zanzibarica (Klotzsch) Bridson ssp. zanzibarica & AJ315105 & AJ620138 \\
\hline Psydrax kraussioides (Hiern) Bridson & AJ617786 & AJ620157 \\
\hline Psydrax livida (Hiern) Bridson & AJ617769 & AJ620158 \\
\hline Psydrax locuples (K. Schum.) Bridson & Aj617770 & Aj620159 \\
\hline Psydrax parviflora (Afzel.) Bridson & Aj315110 & AJ620162 \\
\hline Pyrostria ampijoroense (Arènes) Razafim., Lantz \& B. Bremer & AJ617766 & AJ719194 \\
\hline Pyrostria hystrix (Bremek.) Bridson & AJ315114 & AJ620168 \\
\hline Pyrostria major (A. Rich. ex DC.) Cavaco & EU 584304 & FN386344 \\
\hline Pyrostria orbicularis A. Rich. ex DC. & EU584285 & FN386347 \\
\hline Pyrostria phyllantoidea (Baillon) Bridson & AJ315115 & AJ620169 \\
\hline Pyrostria revoluta (Balf. f.) Razafim., Lantz \& B. Bremer & AJ617776 & AJ620176 \\
\hline Pyrostria sarodranensis Cavaco & EU584280 & FN386366 \\
\hline Pyrostria serpentina Lantz, Klack. \& Razafim. & EU584283 & FN386350 \\
\hline Vangueria infausta Burchell & AJ617777 & AJ620180 \\
\hline Vangueria proschii Briq. & AJ875009 & AJ874975 \\
\hline
\end{tabular}


Table 1 Nucleotide sequence database accession numbers of taxa used in this study (Continued)

\begin{tabular}{lll}
\hline Vangueria parvifolia Sond. & AJ315092 \\
Ixora coccinea L. & AJ224826 & AJ620117 \\
Mussaenda erythrophylla Schumach. \& Thonn. & AJ224823 & AJ620116 \\
\hline
\end{tabular}

Since vouchers of most taxa included in the study were published only the voucher information of the Philippine Canthium included in the study are provided as footnotes.

${ }^{1}$ Philippines, Province of Palawan, Arriola and Alejandro 12442 (USTH).

${ }^{2}$ Philippines, Province of Davao, Lemana and Alejandro BL10014 (USTH).

${ }^{3}$ Philippines, Province of Isabela, Lemana and Alejandro BA10017 (USTH).

${ }^{4}$ Philippines, Province of Quezon, Arriola and Alejandro S001 (USTH).

were a total of three million running generations. Clades with posterior probability (PP) exceeding 0.95 were regarded as strongly supported.

Parsimony analysis was conducted using PAUP version4.0b (Swofford 2000). Heuristic search was carried out to determine the most parsimonious trees utilizing a treebisection reconnection (TBR) branch swapping using 10,000 random addition sequences, with MULTREES option on. Consistency index (Kluge and Farris 1969) and retention index (Farris 1989) were calculated to determine if the data is far from being homoplasious. Bootstrapping was determined using 10,000 replicates, MULTREES option off, TBR branch swapping, and five random addition sequences. Clades receiving greater than $90 \%$ were considered strongly supported.

\section{Results}

\section{Sequence characteristics}

Table 2 shows the matrix characteristics of the separate and combined ITS and trnL-F data sets. The aligned matrix of the 43 taxa of the ITS region includes a total of 691 positions, 190 base pairs (bp) of which are phylogenetically informative. The 43 sequences of $t r n L-F$, have a total of 1,002 positions, $43 \mathrm{bp}$ of which are informative. The combined ITS/trnL-F of the 43 taxa with 1,693 characters generated a total of 233 bp informative characters.

\section{Phylogenetic analysis}

The tree topologies of the separate ITS $(\mathrm{PP}=1.00 ; \mathrm{BS}=$ $100 \%)$ and trnL-F (PP $=0.89 ; \mathrm{BS}=90 \%)$ analyses (trees not shown) revealed a monophyletic Vanguerieae. Both trees resolved the phylogenetic positions of $C$. obovatifolium, C. oligophlebium and C. ramosii in Pyrostria clade

Table 2 Matrix characteristics of separate and combined datasets

\begin{tabular}{llll}
\hline & ITS & trn L- $\boldsymbol{F}$ & Combined \\
\hline Number of taxa & 43 & 43 & 43 \\
Number of included characters & 691 & 1,002 & 1,693 \\
Number of informative characters & 190 & 43 & 233 \\
Consistency index & 0.56 & 0.93 & 0.64 \\
Retention index & 0.74 & 0.93 & 0.76 \\
\hline
\end{tabular}

with high support in ITS (PP $=0.96$; $\mathrm{BS}=89 \%)$ and trnL$F(\mathrm{PP}=1.00 ; \mathrm{BS}=85 \%)$. However, both separate analyses failed to resolve the placement of C. gynochthodes within the tribe and polytomies were observed for members of Canthium s.s and Psydrax.

Bayesian and parsimony analyses of the combined ITS/ trnL-F data sets (Figure 1) shows a robustly supported Vanguerieae ( $\mathrm{PP}=1.00 ; \mathrm{BS}=99 \%$ ) (Figure 1). The majority rule consensus tree of the combined ITS/trnL-F data sets (Figure 1) supports the monophyly of the included genera and recovered tree topologies similar with Lantz and Bremer (2004). For instance, the monophyly of Canthium s.s. is supported ( $\mathrm{PP}=0.96$; $\mathrm{BS}=67 \%)$ and is closely related to the large flowered group ( $\mathrm{PP}=1.00 ; \mathrm{BS}=85 \%$ ); Keetia $(\mathrm{PP}=1.00 ; \mathrm{BS}=64 \%)$ and Afrocanthium $(\mathrm{PP}=1.00$; $\mathrm{BS}=89 \%)$ as sister taxa is likewise supported $(\mathrm{PP}=0.98$; $\mathrm{BS}=72 \%$; ; and the monophyly of Psydrax ( $\mathrm{PP}=0.94$; $\mathrm{BS}=85 \%)$ and Pyrostria s.s. $(\mathrm{PP}=0.99 ; \mathrm{BS}=85 \%)$ were also sustained. The combined data analysis agrees with single marker analyses on the close relatedness of C. obovatifolium, C. oligophlebium and C. ramosii with Pyrostria $(\mathrm{PP}=0.99 ; \mathrm{BS}=85 \%)$. Meanwhile, $C$. gynochthodes is finally resolved within Psydrax ( $\mathrm{PP}=0.94 ; \mathrm{BS}=85 \%$ ).

\section{Discussion}

\section{Generic affiliations of species under Pyrostria group B}

The results presented above clearly shows the polyphyly of Canthium as earlier observed by Lantz et al. (2002), Lantz and Bremer $(2004,2005)$ and Razafimandimbison et al. (2009). The four Canthium (C. gynochthodes, C. obovatifolium, C. oligophlebium and C. ramosii) should be excluded from Canthium s.s. since these species are spineless.

The phylogenetic position of C. obovatifolium, C. oligophlebium and C. ramosii within the Pyrostria clade was already anticipated due to the presence of a persistent, basally paired, connate to acuminate bracts as observed in our recent collections and available herbarium sheets. The synapomorphic characters of Pyrostria such as dioecious sexuality and fleshy corolla with trichomes in the throat (Lantz and Bremer 2004) were also observed in our sampled Canthium species. The placement of these three Canthium species in Pyrostria s.l. was already suggested by Bridson (1987) but she was unsure of the placement in 


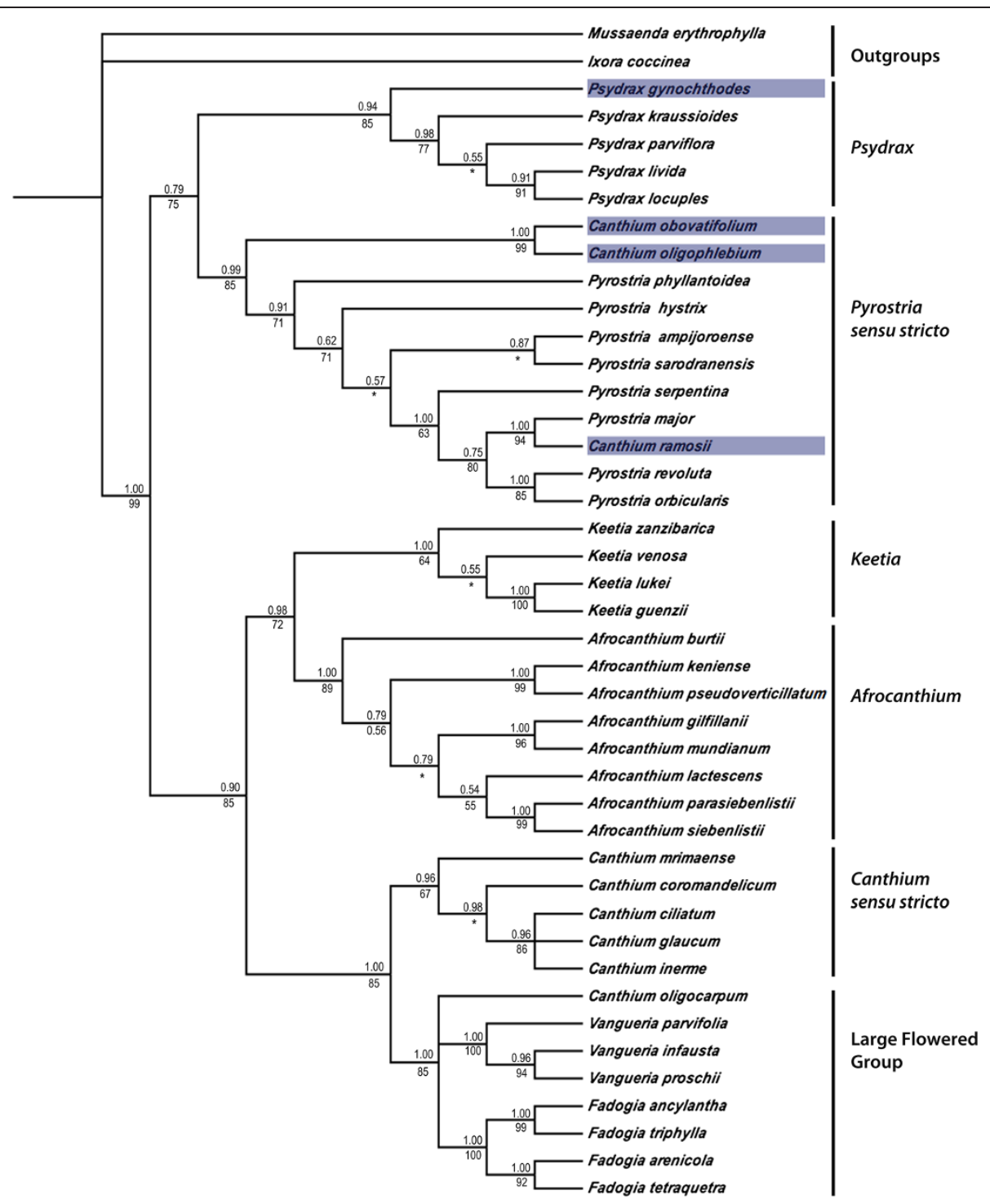

Figure 1 Majority-rule consensus tree inferred from the Bayesian analysis of the combined ITS/trnL-F datasets of the 43 included taxa. The results are congruent with the results of parsimony analysis except for the nodes marked with asterisks. Numbers above branches indicates Bayesian posterior probabilities and those below branches are parsimony bootstrap values. Species under study are highlighted in grey.

the genus due to their geographical occurrence falling outside the known range, i.e. at that time Pyrostria was considered to be a predominately Afro-Madagascan genus.

Although Pyrostria is mostly represented in Africa, Ruhsam et al. (2008) mentioned that the presence of SE Asian Pyrostria could probably be a disjunct part of their African relatives. There is a possibility that species under this genus may have undergone long range dispersal from Africa to Asia as in the case of Mussaenda L. (Alejandro et al. 2005).

Meanwhile, the phylogenetic placement of C. gynochthodes within Psydrax does not support the earlier suggestion of Bridson (1985) in placing the species under Pyrostria s.l.. Bridson may have assigned this SE Asian species under Pyrostria group B due to the presence of bracts which resembles that of Pyrostria although Baillon (1879) did not mention the occurrence of this character. However, we examined herbarium sheets of C. gynochthodes [Gaerlan, F.J.M 0542753 (L, PNH); Romero, E.M. 0542751 (L, PNH); Soejarto, D.D. 0219674 (L, PNH); Arriola and Alejandro, 12442 (PNH, USTH); Arriola and Alejandro, 11057 (PNH, USTH)] and revealed that bracts exist in younger inflorescences but totally absent in older ones. The presence of bracts on young inflorescences of C. gynochthodes will not affect its close relatedness with Psydrax. According to Bridson (1987) bracts may be present in some representatives of Psydrax, however, it is distinctive from the paired connate bracts of Pyrostria 
which are rare in Vanguerieae. The presence of bracts is not a cardinal character to delimit Psydrax. For instance, Bridson (1985) mentioned of the occurrence of bracts in the Indian Psydrax umbellata (Whit.) Bridson and unnamed Malayan species. Furthermore, examination of $C$. gynochthodes revealed that it posseses other diagnostic features of Psydrax such as coriaceous leaf blades, keeled stipules with truncate to triangular stipular base and falcate stipular apex, reflexed anthers, long style always exceeding the corolla tube, longer than wide stigmatic knob, cartilaginous seed and a very shallow to nearly inconspicuous apical crest without a lid-like area in the pyrene (Bridson 1985; Cheek and Sonke 2004). Additionally, the occurrence of a unique insertion of $40 \mathrm{bp}$ in the trnL-F region of Psydrax that is non-alignable with other species of Vanguerieae (Lantz and Bremer 2004) exists in C. gynochthodes.

The close relatedness of species placed under Pyrostria group B with Pyrostria s.s. and Psydrax are supported by morphology and molecular data. Therefore, it is necessary to recollect the remaining species of Pyrostria group B to determine their correct generic affiliations within the tribe.

\section{Taxonomic treatment}

We present here novel combinations of four species that were included in our study (Figure 2).

Pyrostria obovatifolia (Merr.) Wong, Magdaleno \& Alejandro, comb. nov. Basionym: Canthium obovatifolium (Merr.) Merr., Philipp. J. Sci. 35 (1928) 8. Plectronia obovatifolia Merr., Philipp. J. Sci. C12 (1917) 167. Philippines, Luzon, Tayabas Prov. Mount Dalindingan, Sept. 1916, Ramos and Edano 26526 (holotype: PNH destroyed; lectotype: designated here K!; isolectotypes: US, HUH) (Figure 2A).

Shrub to small tree less than $3 \mathrm{~m}$ high; branches terete to a more or less quadrangular and glabrous. Leaves obovate, $3.5-7.5 \times 1.0-3.0 \mathrm{~cm}$, glabrous on both sides; apex rounded; base acute to acuminate; visible lateral nerves 3 to 4 on each side of the midrib; petiole $2.5-8.0 \mathrm{~mm}$, glabrous. Stipules triangular to broadly ovate, $5.0-6.0 \times$ $1.0 \mathrm{~mm}$, glabrous on both sides. Female inflorescences axillary on $3.0-5.5 \mathrm{~mm}$ long peduncles, 6-flowered; peduncular bracts present, $3.0-5.5 \mathrm{~mm}$ long, triangular to broadly triangular, glabrous on both sides, enclosing the young inflorescence; pedicels erect, $3.0-4.0 \mathrm{~mm}$ long at flowering. Female flowers: calyx limb glabrous; tube 1.2- $2.5 \mathrm{~mm}$ long; lobes acuminate, $0.2 \times 0.4 \mathrm{~mm}$. Corolla 5-merous, white, glabrous outside; tube tubular, 0.8$1.2 \mathrm{~mm}$ long, hairs present at the throat; lobes broadly triangular, $2.0-2.5 \times 1.0-1.2 \mathrm{~mm}$, recurved. Stamens exerted, attached to corolla tube; anthers narrowly ovate to ovate, $0.3 \mathrm{~mm}$ long, exserted. Style including stigmatic knob 3.0-3.9 mm long; stigmatic knob $1 \mathrm{~mm}$ long, with a shallow cleft above, style not recessed into the stigmatic head; disk glabrous. Ovary 2-locular. Male flower unknown. Fruits ovoid $8.5-10.5 \mathrm{~mm}$, glabrous.

Distribution:-Luzon Island: Ilocos Norte, Quezon

Habitat:-In secondary forest; $200-350$ m altitude.

Phenology:-Flowering from March to June; Fruiting May to December

Taxonomic notes: This species approaches $P$. subsessifolia by its elliptic to ovate leaf shape but differs by its less conspicuous lateral nerves, shorter bracts and nonkeeled fruits.

Pyrostria oligophlebia (Merr.) Pacia, Quiogue \& Alejandro, comb. nov. Basionym: Canthium oligophlebium (Merr.) Merr., Philipp. J. Sci. 35 (1928) 8. Plectronia oligophlebia Merr., Philipp. J. Sci. 17 (1921) 442. Philippines, Luzon, Rizal Prov. Mount Susong Dalaga, Aug. 1917, Ramos and Edano 29342 (holotype, PNH destroyed; lectotype: designated here US; isolectotype: $\mathrm{HUH}, \mathrm{K}$ !) (Figure 2B)

Shrub to small tree, less than $5.0 \mathrm{~m}$ high; branches quadrangular to more or less terete and glabrous. Leaves broadly lanceolate to oblong, $3.0-5.5 \times 1.0-2.0 \mathrm{~cm}$, glabrous on both sides; apex acute; base acute; visible lateral nerves 2 to 4 on each side of the midrib; petiole $0.7-$ $1.0 \mathrm{~mm}$, glabrous. Stipules broadly triangular to ovate, $1.0-2.0 \times 1.0 \mathrm{~mm}$, glabrous on both sides. Female inflorescences axillary on a glabrous peduncle less than $2 \mathrm{~mm}$ long, 7-12 flowered; peduncular bracts present, 2.5-3.0 mm long, triangular to broadly triangular, glabrous on both sides, enclosing the young inflorescence; pedicels erect, $4.0-5.0 \mathrm{~mm}$ long at flowering, persistent.

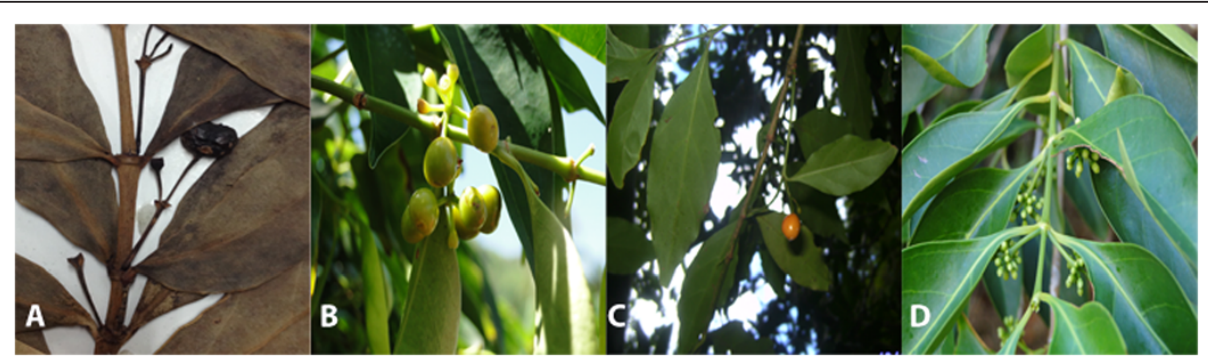

Figure 2 Images of the four plant species included in the study. A. Pyrostria obovatifolia fruiting branch; B. Pyrostria oligophlebia infructiscences; C. Pyrostria ramosii fruiting branch; D. Psydrax gynochthodes flowering branch. 
Female flowers: calyx limb glabrous $2-2.7 \mathrm{~mm}$ long; lobes shortly toothed, $0.1 \times 0.3 \mathrm{~mm}$. Corolla 4-merous, white, glabrous outside; tube tubular, 0.8-1.2 mm long, hairs present at the throat; lobes broadly ovate, 2.0$2.5 \times 1.0-1.2 \mathrm{~mm}$. Stamens attached to corolla tube adjacent to the throat; anthers ovate, $0.3 \mathrm{~mm}$ long, exserted. Style including stigmatic knob 1.0-2.5 mm long; stigmatic knob $1 \mathrm{~mm}$ long, with a shallow cleft above; disk glabrous. Ovary 2-locular. Male flower unknown. Fruits ovoid 6.0$6.5 \mathrm{~mm}$, glabrous with distinct indentation when dry.

Distribution:-Luzon Island: Rizal;

Mindanao Island: Davao

Habitat:-In secondary forest; 500-900 m altitude.

Phenology:-Flowering from March to December; Fruiting from Septmber to February

Taxonomic notes: The smaller and fewer nerved leaves of P. oligophlebia approaches P. gynochthodes. However, $P$. oligophlebia differs from the latter by having persistent pair of bracts, many-flowered inflorescences and a longer petioles, peduncles and pedicel.

Pyrostria ramosii (Merr.) Arriola, Paraguison \& Alejandro, comb. nov.

Basionym: Canthium ramosii (Merr.) Merr., Philipp. J. Sci. 35 (1928) 9. Plectronia ramosii Merr., Philipp. J. Sci. 7 (1921) 443. Philippines, Luzon, Tayabas Prov., Mount Umiray, June 1917, Ramos and Edano 28973 (holotype, PNH destroyed; lectotype: designated here NY!; isolectotype: $\mathrm{K}$ !) (Figure 2C)

Tree less than $9 \mathrm{~m}$ high; branches terete, glabrous. Leaves broadly lanceolate to oblong, $2.5-9.5 \times 1.5-3.9 \mathrm{~cm}$, glabrous on both sides; apex triangular to acuminate; base attenuate; visible lateral nerves 3 to 4 on each side of the midrib; petiole $1.5-2.0 \mathrm{~mm}$, glabrous. Stipules triangular, $3.5-4.0 \times 1.5-2.0 \mathrm{~mm}$, glabrous on both sides. Inflorescences 4 flowered umbels; pedicels erect, $6.5-7.0 \mathrm{~mm}$, persistent glabrous, peduncular bracts present, 0.5$1.5 \mathrm{~mm}$ long, triangular, glabrous on both sides. Infructiscence glabrous; stalk glabrous. Fruits ovoid to didymous 6.5-8.5 mm, 2 -celled, glabrous.

Distribution:-Luzon Island: Quezon

Habitat:-In secondary forest; 200-350 m altitude.

Phenology:- Fruiting August to December

Taxonomic notes: Pyrostria oligophlebia and P. ramosii closely resemble each other due to their oblong shape leaf with acuminate apex. However, the latter have longer peduncles and few (2-4) flowered umbellate inflorescences as compared to the numerous (7-12) flowered inflorescence of the former.

Psydrax gynochthodes (Baill.) Arriola, Yayen \& Alejandro, comb. nov.

Basionym: Plectronia gynochthodes (Baill.) Merr., Enum. Philipp. Fl. Pl. 3 (1923) 536. Canthium gynochthodes Baill., Adansonia 12 (1879) 199. Philippines, Luzon, Batangas Prov., 1917, Cuming 1848 (holotype, K!) (Figure 2D)
Tree, less than $7 \mathrm{~m}$ tall; branches flattened to subterete, glabrous. Stipules glabrous on both sides, triangular to ovate, $2-4.5 \mathrm{~mm}$, keel prominent on the abaxial side. Petioles $1.0-5.0 \times 0.3-0.5 \mathrm{~mm}$, glabrous; leaf blades leathery, elliptic to elliptic-oblong or obovate, 3-8.5 × 1.5$5 \mathrm{~cm}$, base acute to broadly acute, apex obtuse, glabrous throughout, glossy; lateral nerves 3-4 on each side of the midrib, domatia present. Inflorescences axillary, 10-12(-several) flowered, glabrous; peduncle $0.8-2.5 \mathrm{~mm}$, glabrous; pedicel $4.0-10.0 \mathrm{~mm}$, puberulent. Calyx tube infundibuliform, $2-3 \times 2.0-2.5 \mathrm{~mm}$, glabrous; lobes triangular 1.5-2.0 mm. Corolla tube infundibuliform, 1.0$1.5 \mathrm{~mm}$, glabrous outside, with ring of white hairs inside; lobes 4, triangular, glabrous outside and inside. Anthers 4, reflexed. Style 2-6 $\mathrm{mm}$, exceeding corolla tube, stigmaticknob longer than wide, $0.3 \times 0.2 \mathrm{~mm}$, bifid. Ovary bilocular, 1-ovule per locule. Fruits ovoid to didymous, distinctly broader than long, 7.5-8.0 ×9-10 mm, green when young, glabrous, calyx limb persistent; Seeds 2, obliquely ovoid, ventrally flattened, $2-5.5 \times 3 \mathrm{~mm}$, apical crest very shallow to nearly inconspicuous, pyrene cartilaginous.

Distribution:-Philippines, Taiwan

Habitat:-In secondary forest; 500-900 m altitude.

Phenology:-Flowering from March to June; Fruiting from June to December

Taxonomic notes: Psydrax gynochthodes is comparable with $P$. obovatifolia, $P$. oligophlebia and $P$. ramosii. However it is delineated from the three species due to the absence of persistent acuminate-connate bracts. For the above reason, we do not agree with the observation of Bridson (1987) that P. gyncochthodes is closely associated with $P$. villarii Vidal and that the two species should be synonymize. Moreover, P. gynochthodes can be distinguised from the Philippine $P$. amplifolia by its smaller, thicker and darker glossy green leaves, umbellate to cymose inflorescences, longer peduncles and smaller fruits.

\section{Conclusion}

The generic affiliations of four species previously hypothesized under Pyrostria group B have been resolved based on morphology and molecular sequence data. We formally proposed three novel combinations in Pyrostria and a Psydrax. Other species of Pyrostria group B should be reinvestigated towards a more natural classfication in Vanguerieae. Furthermore, large number of Pyrostria and bracteate species temporarily placed under Canthium s.l should be sampled to fully understand the evolutionary dispersal of the genus.

Competing interests

The authors declare that they have no competing interests. 


\section{Authors' contributions}

GJDA and AHA drafted the manuscript; All authors participated in sample collection, molecular work and taxonomic treatment. All authors read and approved the final manuscript.

\section{Acknowledgements}

We thank the following herbaria and staff for providing loans and/or access to collections: K, L, NY, P, PNH, US and USTH. The authors thank the Research Center for Natural \& Applied Sciences (RCNAS), University of Santo Tomas and the Commission on Higher Education, Philippine Higher Education Research Network (CHED-PHERNEt) for the funding.

\section{Author details}

${ }^{1}$ College of Science, University of Santo Tomas, España, Manila 1015, Philippines. ${ }^{2}$ Research Center for the Natural \& Applied Sciences, University of Santo Tomas, España, Manila 1015, Philippines. ${ }^{3}$ The Graduate School, University of Santo Tomas, España, Manila 1015, Philippines. ${ }^{4}$ Department of Biological Sciences, College of Arts and Sciences, University of the East, 2219 C.M. Recto Ave, Manila, Philippines

Received: 21 November 2013 Accepted: 5 August 2014 Published online: 11 September 2014

\section{References}

Akaike H (1974) A new look at the statistical model identification. IEEE Trans Autom Control 19:716-723

Alejandro GJD, Razafimandimbison SG, Liede-Schumann S (2005) Polyphyly of Mussaenda inferred from ITS and trnT-F data and its implication for generic limits in Mussaendeae (Rubiaceae). Am J Bot 92:544-557

Alejandro GJD, Meve U, Mouly A, Thiv M, Liede-Schumann S (2011) Molecular phylogeny and taxonomic revision of the Philippine endemic Villaria Rolfe (Rubiaceae). Plant Syst Evol 296:1-20

Alejandro GJD, Arenas EH, Cremen CM, Arriola AH (2013) A new record of Pyrostria (Vanquerieae-Rubiaceae) from the Philippines inferred from molecular and morphological data. Phil J Syst Bio 8:1-12

Alterkar G, Dwarkadas S, Huelsenbeck JP, Ronquist F (2004) Parallel metropolis coupled Markov chain Monte Carlo for Bayesian phylogenetic inference. Bioinformatics 20:407-415

Baillon HE (1879) Canthium gynochthodes. Adansonia 12:199

Bridson DM (1985) The reinstatement of Psydrax (Rubiaceae, subfam. Cinchonoideae tribe Vanguerieae) and a revision of the African species. Kew Bull 40:687-725

Bridson DM (1986) The reinstatement of the African genus Keetia (Rubiaceae subfam. Cinchonoideae, tribe Vanguerieae). Kew Bull 41:965-994

Bridson DM (1987) Studies in African Rubiaceae- Vanguerieae: a new circumscription of Pyrostria and a new subgenus, Canthium subgen. Bullockia. Kew Bull 42:611-639

Bridson DM (1992) The genus Canthium (Rubiaceae- Vanguerieae) in tropical Africa. Kew Bull 47:353-401

Chase MW, Hills HH (1991) Silica gel: an ideal material for preservation of leaf samples for DNA studies. Taxon 40:215-220

Cheek M, Sonke B (2004) Psydrax bridsoniana (Rubiaceae), a new species of tree from western Cameroon. Kew Bulletin 59:605-608

Farris JS (1989) The retention index and the rescaled consistency index. Cladistics 5:417-419

Huelsenbeck JP, Ronquist F (2001) MRBAYES: Bayesian inference of phylogenetic trees. Bioinformatics 8:754-755

Kluge AG, Farris JS (1969) Quantitative phyletics and the evolution of anurans. Syst Zool 18:1-32

Lantz H, Bremer B (2004) Phylogeny inferred from morphology and DNA data: characterizing well-supported groups in Vanguerieae (Rubiaceae). Bot J Linn Soc 146:257-283

Lantz H, Bremer B (2005) Phylogeny of the complex Vanguerieae (Rubiaceae) genera Fadogia, Rytigynia, and Vangueria with close relatives and a new circumsumption of Vangueria. Plant Syst Evol 253:159-183

Lantz H, Andreasen K, Bremer B (2002) Nuclear rDNA ITS used to construct the first phylogeny of Vanguerieae (Rubiaceae). Plant Syst Evol 230:173-187

Popp M, Oxelman B (2001) Inferring the history of the polyploid Silene aegaea (Caryophyllaceae) using plasmid and homoeologous nuclear DNA sequences. Mol Phylogenet Evol 20:474-481
Rambaut A (1996) Se-Al v1.0a1. http://tree.bio.ed.ac.uk/software/seal/. Accessed 15 May 2011

Razafimandimbison SG, Lantz H, Mouly A, Bremer B (2009) Evolutionary trends, major lineages and new generic limits in the dioecious group of the tribe Vanguerieae (Rubiaceae): insights into the evolution of functional dioecy. Ann Mo Bot Gard 96:161-181

Ronquist F, Huelsenbeck JP (2003) MrBayes 3: Bayesian phylogenetic inference under mixed models. Bioinformatics 19:1572-1574

Ruhsam M, Govaerts R, Davis AP (2008) Nomenclatural changes in preparation for a World Rubiaceae Checklist. Bot J Linn Soc 157:115-124

Schwartz G (1978) Estimating the dimensions of a model. Ann Stat 6:461-464

Swofford DL (2000) PAUP*: Phylogenetic Analysis Using Parsimony (*and other methods) version 40b. Sinauer Associates, Sunderland, MA

Taberlet P, Gielly L, Pautou G, Bouvet J (1991) Universal primers for amplication of three non-coding regions of chloroplast DNA. PI Mol Biol 17:1105-1109

Utteridge TMA, Davis AP (2009) Two new combinations in Pyrostria (Rubiaceae-Vanguerieae) from Thailand. Kew Bull 64:751-752

Verdcourt B (1987) Notes on African Rubiaceae: Vanguerieae. Kew Bull 42:123-199

doi:10.1186/s40529-014-0065-3

Cite this article as: Alejandro et al:: Generic affiliations of Canthium species placed under Pyrostria group B sensu Bridson (Vanguerieae, Rubiaceae) inferred from morphology and molecular data. Botanical Studies 2014 55:65

\section{Submit your manuscript to a SpringerOpen ${ }^{\circ}$ journal and benefit from:}

- Convenient online submission

- Rigorous peer review

- Immediate publication on acceptance

- Open access: articles freely available online

- High visibility within the field

- Retaining the copyright to your article

Submit your next manuscript at springeropen.com 